\title{
Microfinance Goes Macro: Impact on Poverty Alleviation in Pakistan
}

\author{
Rizwana Bashir \\ Dr. Shafeeq-ur-Rehman
}

\begin{abstract}
Today one of the most compelling challenges facing Pakistan is the problem of poverty. In the quest for solutions to the country's development challenge and poverty alleviation, microfinance is becoming one of the most admired options as credit has been identified as a barrier facing the poor, especially the rural poor. The overall aim of this paper is to explore the impact of microfinance on alleviating poverty. Pakistan's poverty reduction strategy has yielded handsome result in the shape of sharp reduction in headcount poverty from 2000-01 to 2005-06. Although, poverty has declined but the fact remains that 22.3 per cent people of Pakistan are still living below the poverty line (Economic Survey of Pakistan 2007-08). Macroeconomic strength is a precondition for the economic growth that fetch the poverty reduction and growing living standards. But macroeconomic stability is not sufficient. Rather, it is the foundation on which to build a flourishing economy. Successfully targeted microfinance programs are also the key to permanent and sustained reduction in poverty. Microfinance institutions can contribute to this by building financial regulation and providing guidance to the borrowers. Operating on these grounds, microfinance institutions can make a big difference in alleviating poverty in Pakistan.
\end{abstract}

Keywords: Microfinance, empowerment of poor, poverty alleviation, consumption loan

\section{Introduction}

Many government programs have tried to alleviate poverty, but the results are often disappointing. The results are affected by corruption and the assistance aids create dependency and discouragement. There is a need to realize that poor do not need subsidy or aid but the credit. In developing countries, low-income households are excluded from the formal banking sector, because the asymmetric information between the bank and the borrowers are too high and cannot be reduced by collaterals. Microfinance institutions seem to have found a sustainable solution. The world confronts the big challenge of reducing poverty. "Of the world's 6 billion people, 2.8 billion live on less than 2 dollar a day and 1.2 billion live on less than 1 dollar a day. Of these 1.2 billion, 500 million live in South Asia". (State Bank Pakistan, First Quarterly Report for FY05, pp.105-112)

In an interview to Time Magazine, Dr. Younus (2006), the originator of the idea of microfinance, said that "our grandchildren will have to go to museums to see poverty.

Rizwana Bashir is a PhD fellow, Department of Economics, University of Karachi, rizb2001@yahoo.com Dr. Shafeeq-ur-Rehman is Chairman, Department of Economics, University of Karachi, shafiq_econ@yahoo.com 
When school children will be on a tour of the poverty museum, they will be horrified to see the misery and indignity of human beings".

Further strengthening his argument he claimed that "58\% of the poor who borrowed from Grameen are now out of poverty. 2005 was declared the Year of Microcredit and there are over 100 million people now involved with micro credit (programs). At the rate we are heading, we will halve total poverty by 2015 . We'll create a poverty museum in 2030". (Paving the Way out of Poverty, Time Magazine, October 13, 2006). Microfinance as term implies, refers to providing small loans to the low-income clients living in both urban and rural areas to kick-start a business in the informal sector. It is a local process and based on local institutions that collect local resources and recollect them locally. Providers of microfinance may include formal-sector institutions (such as, commercial banks); semiformal bodies such as non-government organizations, cooperatives; and other informal savings and credit institutions.

When poverty is not addressed seriously and quickly, it may cause serious dents on Socio-economic structure of the society. When poor is denied of access to his basic rights, such as, justice, education, employment, health, shelter, etc., he could turn into a burning flame. While talking about the role of MFIs in poverty reduction, two questions arise. First, whether micro-credit increases earning capacity of the poor families that is sufficient enough to move them out of the poverty trap. Second, whether the poverty alleviation is on sustainable basis or is it a temporary phenomenon. While majority of studies answer the first question, there is a need to explore the answer of the second question to assess the sustainability of microfinance impact on the poverty eradication. Overall aim of this paper is to explore the impact of microfinance on alleviating poverty. In particular we examine evidence on following specific issues:

- The success of microfinance programs in reaching the core poor;

- The effectiveness of microfinance initiatives in pulling households out of poverty

- The cost effectiveness of microfinance as a poverty targeting tool.

\section{Review of Literature}

\subsection{Poverty: An Overview}

"The World Bank's upper poverty line (1985), the Afro-Equa-Bengal poverty line, below which persons are designated as poor, was 370 purchasing power adjusted dollar or I\$370 per year". (Nafziger, 1997, pp. 127-128)

Absolute Poverty is a term used to explain the severity of the poverty by the World Bank. It has a criterion of $\$ 275$ per person per year. "Meaning, any household with an income in 1985 purchasing power parity dollars below $\$ 275$ was classified as extreme poor. This yardstick does not know any boundaries, and is independent of the level of national per capita income, and takes into account different price levels by measuring poverty as anyone living on less than \$1 a day". (Nafziger, E. Wyne 1997, pp. 127-128) 


\subsubsection{Incidence of Poverty in Pakistan}

According to the very latest Human Development Report of UNDP (2009), Pakistan ranked at 101st on human poverty index out of 182 countries with poverty level of $33.4 \%$ and it ranks at 141 st on human development index. It indicates dire need to address the problem of poverty on emergency basis.

According to Economic Survey of Pakistan (2004-05), "during the five decades from 1950 to 2001, the population of Pakistan has increased 4.3 times - from 33 million to 140.36 million. Over the same period, the per capita income in Pakistan increased by only 5 times from $\$ 79$ in 1950 to $\$ 503$ in 2001". This raise in per capita income is very low as compared to other developing countries.

We can examine (from Table 2.1) that urban poverty fell between 1992/93 and 2002/03 from 28.3 per cent to 22.39 per cent, whereas rural poverty increased from 24.6 per cent to 38.65 per cent, a considerable widening of the urban-rural gap.

Table 2.1: Trends in Poverty: Headcount Ratio (in per cent)

\begin{tabular}{|l|c|c|c|c|c|c|c|c|c|c|}
\hline & FY87 & FY88 & FY91 & FY93 & FY94 & FY97 & FY99 & FY01 $^{* *}$ & FY03 $^{* * *}$ \\
\hline Pakistan & 29.1 & 29.2 & 26.1 & 26.8 & 28.7 & 29.8 & 30.6 & 32.1 & 31.8 \\
Urban & 29.8 & 30.3 & 26.6 & 28.3 & 26.9 & 22.6 & 20.91 & 22.67 & 22.39 \\
Rural & 28.2 & 29.3 & 25.2 & 24.6 & 25.4 & 33.1 & 34.67 & 38.99 & 38.65 \\
\hline
\end{tabular}

Source: Economic Survey, 2003, Government of Pakistan.

*The Headcount ratio is based upon the officially notified national poverty line of Rs.673.54 per capita per month at the prices of 1998-99, Pakistan Integrated Household Survey (PIHS).

** The Headcount ratio is based upon the officially notified national poverty line of Rs.748.56 per capita per month at the prices of 2000-01 PIHS Survey.

*** The Headcount ratio is based on the post enumeration survey of PIHS 2000-01, with 5\% representative sample covering 726 households out of the original sample size of14536 households, was conducted in February 2003.

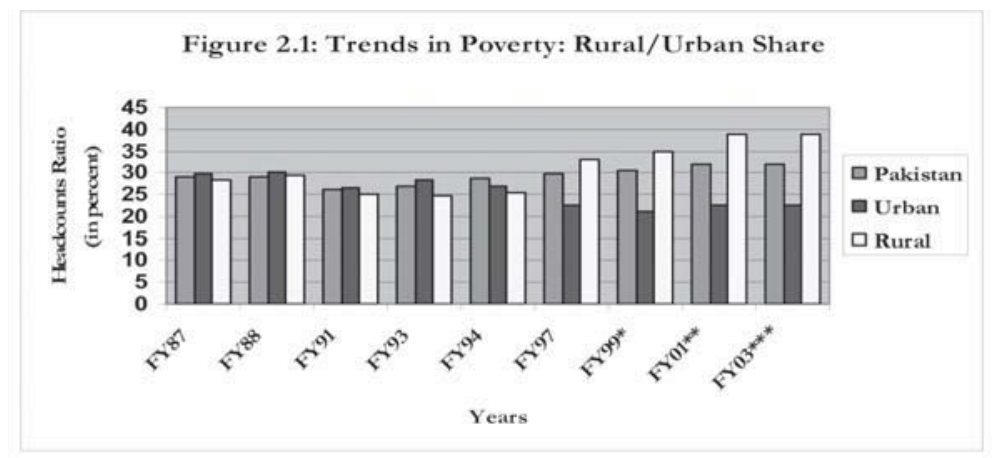

Source: Extracted from Table 2.1. 
We can also observe that the share of rural poverty in the poverty of Pakistan is greater and on a continues rise as compared to urban poverty between 1996/97 and 2002/03.

\subsection{Microfinance: An Overview}

"Money makes money. When you have got a little, it is often easy to get more. The great difficulty is to get that little." (Adam Smith)

Microfinance, as the term implies, refers to providing small loans to the low-income clients living in both urban and rural areas to kick-start a business in the informal sector. Providers of microfinance may include formal-sector institutions (such as, microfinance banks); semiformal bodies such as non-government organizations (NGOs), cooperatives; and other informal savings and credit institutions. Over the last ten years, successful experiences in providing finance to small entrepreneur and producers demonstrate that poor people, when given access to financial services at market rates, repay their loans and use the proceeds to increase their income and assets. State Bank of Pakistan (2005) describes that Microfinance Institutions (MFIs) are a substitute for informal sources of financing which requires no security.

\subsubsection{Microfinance as an Anti-Poverty Strategy}

In Pakistan, microfinance is gaining importance as an effective tool of social mobilization and poverty alleviation. The major objectives, described in First Quarterly Report of State Bank of Pakistan (2005), of micro credit schemes are to reduce poverty through empowerment of poor people by providing them less costly loans and creating employment opportunities. Currently in Pakistan, a variety of institutions ranging from NGOs to private and government sponsored rural support programs are delivering microfinance services to the poor. However, the microfinance service market in Pakistan remains underdeveloped and serves only 7 to 8 per cent of these potential clients. If microfinance is to serve a large share of the market, practitioners must improve their programs by enhancing their outreach access to the potential clients.

Microcredit helps in reducing poverty by providing the poor with credit facility to start a small business. It not only supports the economic condition of the poor people but also has positive impacts on their social life through better standard of living with greater access to education and health facilities and empowerment to participate in decisions of the society.

\subsubsection{Microfinance in Pakistan}

The microfinance program has been functioning in Pakistan in one form or the other since 1970s. It was first launched by the then government to attack poverty. According to Economic Survey of Pakistan (2006-07), microfinance has been recognized as an important instrument for poverty reduction in the first generation Pakistan Rural Support Programs (PRSP-I). Realizing the need and importance of microfinance, as a tool of poverty reduction and social mobilization, the government has accelerated its efforts 
to establish strong foundations of microfinance in formal sector and extended considerable support to the informal sector (NGOs) as well.

In order to promote the microfinance in formal sector, the most significant step taken by the government was the launching of Microfinance Sector Development Program (MSDP) in 2000. The main objective of this program was to broaden and enhance the pace for the development of the sector to provide the financial services to poor on sustainable basis. Khushali Bank (KB), the first specialized microfinance bank, was established in 2000 under a special ordinance.

Then Microfinance Institutions (MFI) Ordinance 2001 was put in place to provide a separate regulatory framework for microfinance sector. Pakistan Poverty Alleviation Fund (PPAF) was also established as a wholesale provider of credit to NGOs. Economic Survey of Pakistan (2007) says that it is estimated that around 40 Microfinance Institutions (MFIs) are operating in various different categories, offering over 400 outlets countrywide. Cumulatively, the outstanding loans of these institutions in 2005-06 amounted to Rs. 6.6 billion. The Microfinance Institutional Framework currently supports one million active borrowers, which are intended to be increased to 3 million by 2010 . As awareness about the MFIs framework grows, microfinance banks are likely to be established in the foreseeable future. Other than conventional microfinance banks, rest of the three categories engaged in providing Microfinance services in Pakistan are as under:

\subsubsection{Non-government Organizations (NGOs)}

This category consists of NGOs working as microfinance institutions as well as those providing microfinance services as part of their multi-dimensional development program. Specifically, Kashf, Sind Agricultural and Forestry Workers Coordination Organization (SAFWCO), Akhuwat, Orangi Pilot Project (OPP), and Asasah are operating as MFls. Development action for mobilization and emancipation (DAMEN), Taraqee Foundation and Sungi are proving microfinance services as a part of their overall incorporated services.

\subsubsection{Rural Support Programs (RSPs)}

These are the programs running microfinance function as a part of their rural development program. At present, four RSPs are in operation, which include National Rural Support Program (NRSP), Punjab Rural Support Program (PRSP), Sarhad Rural Support Program (SRSP) and Thardeep Rural Development Program (TRDP).

\subsubsection{Commercial Financial Institutions (CFIs)}

CFIs are the institutions in the conventional financial sector, providing microfinance as a separate function within the broader organizational framework. For example two CFls are Orix Leasing and The Bank of Khyber. 


\subsubsection{Microfinance: A Tool of Development}

Although microfinance is not a new concept, the current popularity of microfinance has its beginning in 1976 when world famous economist Muhammad Yunus initiated providing small amounts of cash (micro-credit) to rural women in Bangladesh to start or expand their businesses. The beneficiaries of these small loans repaid them on time and ran successful ventures; this in turn encouraged Dr. Yunus to expand his lending program which has become the famous Grameen Bank now. Since 1976, Grameen has handed out 3.12 million borrowers and disbursed $\$ 4.18$ billion loans. (Yunus, 2004) Providing credit to those who are not otherwise served by formal financial sector institutions caught attention internationally, and the Grameen approach spread rapidly during the 1980s and 1990s. The target clientele for microfinance services include female heads of households, pensioners, displaced persons, retrenched workers, small farmers, and micro-entrepreneurs, each of whom falls into one of four poverty levels: destitute, extreme poor, moderate poor and vulnerable non-poor. This further witness the efficiency of microfinance in reaching all categories of poor. With the geographic expansion of microfinance has come an explosion of organizations providing credit to the poor. Today, microfinance providers offer credit to some 20 million households worldwide.

Within the cadre of organizations and non-governmental organizations (NGOs) who support, fund, or deliver microfinance services, several trends are evident. These include an increasing focus on savings mobilization, a broadening of acceptable loan use from solely income-generating purposes (e.g. micro-enterprises) to consumer purposes (e.g. education and health needs), a shifting of focus from credit provision to institutional sustainability and financial intermediation, and the extension of the scale and depth of microfinance institutions (MFIs). In short, the financial systems approach is becoming the dominant paradigm in the microfinance world-or at least seems to be gripping the bulk of the ink being spilled in the movement.

\section{Research Methodology}

In this research, methodology includes primary as well as secondary data analysis. For collection of primary data research tool used is questionnaire and it covers the data collection period of 2006 to 2008 . Equal importance is given to qualitative and quantitative data both. Secondary data analysis and case histories were used in the early stages. A variety of sources were helpful for gathering secondary data including economic surveys of Pakistan and various periodic publication of Pakistan Microfinance Network. Secondary data analysis was helpful in connecting what has been done earlier and findings of the current research.

\section{Does Microfinance Alleviate Poverty? Facts and Analysis}

\subsection{Facts}

Economic Survey of Pakistan (2007-08), gives a comparative picture of poverty during 2000-01 and 2005-06. The latest estimate of inflation-adjusted poverty line for 2005- 
06 is Rs.944.47 per adult equivalent per month, up from Rs.878.64 in 2004-05. Headcount ratio, i.e., percentage of population below the poverty line has fallen marginally from 23.94 per cent in 2004-05 to 22.32 per cent in 2005-06, an improvement of 1.62 per centage points. Poverty in rural areas declined from 28.13 per cent to 27.0 per cent, showing an improvement of 1.13 percentage points between 2004-05 and 2005-06.

Table 4.1: Population under various Poverty bands (\% of Population)

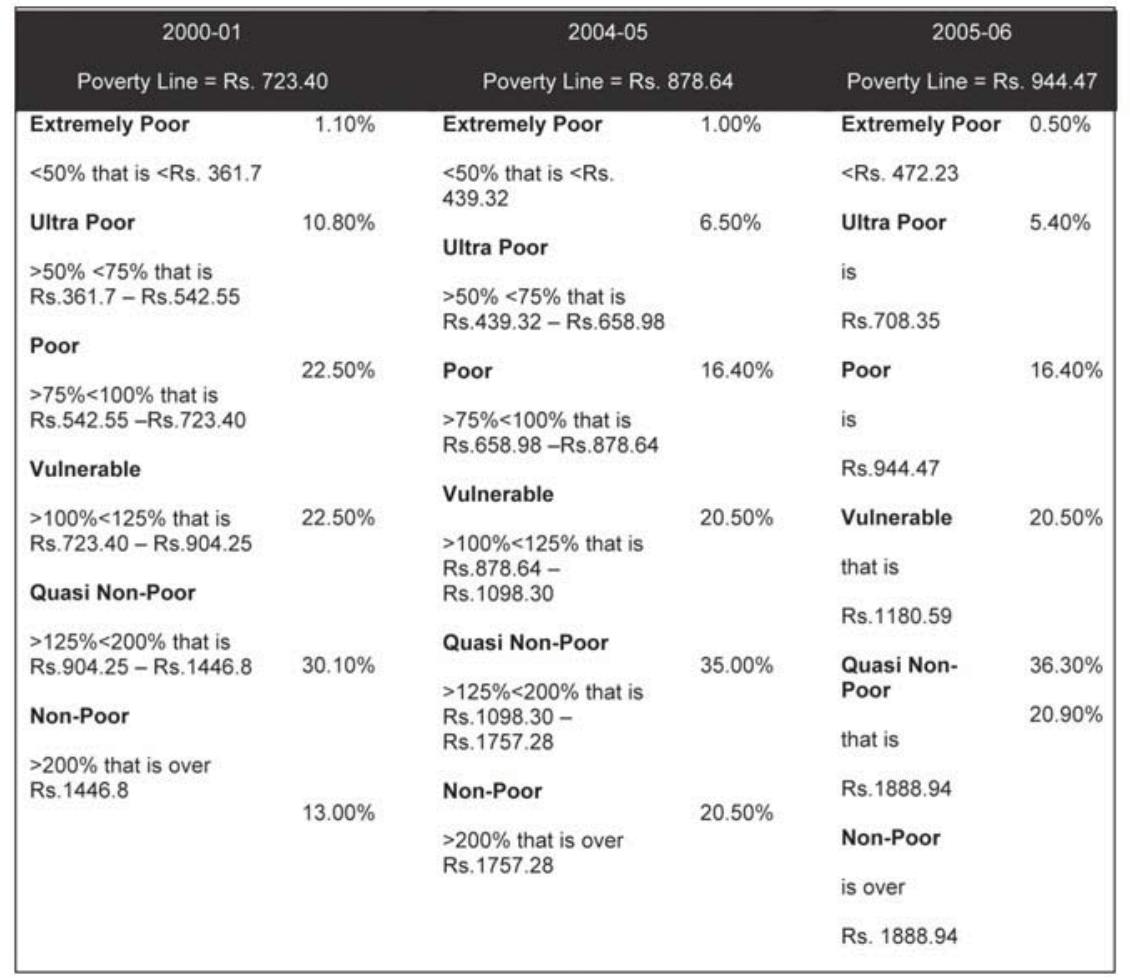

Source: Pakistan Economic Survey 2007-08, p. 217.

Poverty in Urban areas also records a decline from 14.94 per cent to 13.1 per cent during 2004-05 and 2005-06, thereby, depicting an improvement of 1.84 percentage points in the period. The improvement in poverty headcount in percentage points terms at 1.9 per cent in urban areas was nearly twice that of rural areas. The estimation of poverty line enables the policy makers to further identify and group the population into various 'poverty bands' such as extremely poor, vulnerable and non-poor etc. For example, extremely poor are those individuals whose per adult equivalent consumption per month is less than $50 \%$ of the poverty line, i.e., below Rs.658.98 in 2004-05. At the other end of the scale are non-poor, whose per adult equivalent consumption per month is more than $200 \%$ of the poverty line, i.e., greater than Rs.1757.28 in 2004-05 (see Table 4.1). 
As shown above in Table 4.1, the percentage of population (1\% of total population) classified as "extremely poor" remained unchanged between the two periods 2004-05 to 2005-06, whereas the proportion of "ultra poor" and "poor" have declined appreciably during the same period. At the higher end, the percentage of "quasi non-poor" and "nonpoor" has increased notably. The percentage of population defined as "vulnerable" have also declined but the state of decline was relatively slower compared with other poverty bands.

\begin{tabular}{|ccccc|ccccc|}
\hline & \multicolumn{3}{c}{ Headcount } & \multicolumn{3}{c}{ Poverty Gap } & \multicolumn{3}{c|}{ Severity of Poverty } \\
\hline Year & Urban & Rural & Pakistan & Urban & Rural & Pakistan & Urban & Rural & Pakistan \\
\hline $1998-99$ & 20.9 & 34.7 & 30.6 & 4.3 & 7.6 & 6.4 & 1.3 & 2.4 & 2.0 \\
$2000-01$ & 22.7 & 39.3 & 34.5 & 4.6 & 8.0 & 7.0 & 1.4 & 2.4 & 2.1 \\
$2004-05$ & 14.9 & 28.1 & 23.9 & 2.9 & 5.6 & 4.8 & 0.8 & 1.8 & 1.5 \\
$2005-06$ & 13.1 & 27.0 & 22.3 & 2.1 & 5.0 & 4.0 & 0.5 & 1.4 & 1.1 \\
\hline
\end{tabular}

Source: Pakistan Economic Survey 2007-08, p. 216

Table 4.2 from Performance Indicators Report (2005), of Pakistan Microfinance Network also gives a snapshot of head count poverty and poverty gap from 1998-99 to 200506 . We can examine that in the year 2000-01 head count poverty increased to its highest from 30.6 per cent in 1998-99 to 34.5 per cent. Urban poverty during the same period increased from 20.9 per cent to 22.7 per cent, whereas rural poverty also increased but with a higher velocity, i.e. from 34.7 per cent to 39.3 per cent. Afterward, we have observed a decreasing trend in poverty. During these years, when poverty is decreasing, there has been huge eagerness around MFIs. In light of the high rate of repayment obtained, funds have been channeled and reallocated from traditional poverty alleviation program to microfinance.

Pakistan Poverty Alleviation Fund was also established in the year 2000, to streamline the flow of poverty alleviation funds to microfinance institutions. Most of the donors assume that these funds should be used only for the start up of the program. Hence, the microfinance institutions have two goals: the financial sustainability in medium term and providing financial services to low-income households in order to alleviate poverty. The combination of these two aims has led to diverse experiences among the microfinance institutions. In fact, low-income households have a highest capacity of saving, which is an important financial source of the microfinance institution. Furthermore, welldesigned lending program can improve their income and in some cases can move them above the poverty line. (Performance Indicators Report 2005, PMN) However, the micro-enterprises can promote economic growth, which as proven in many studies, reduce poverty. Richard Adams (2003), a poverty specialist with the World Bank's Poverty Reduction Network, researched from 50 developing countries to examine the impact of economic growth on poverty and inequality. His research suggests that growth represents an important means for dropping poverty in the developing world. When economic growth is measured by survey mean income (consumption), there is strong, statistical link between economic growth and poverty reduction. 
Pakistan Economic Survey (2006-07), enumerate that strong economic growth, large inflow of remittances and Rs. 2217 billion spending on social sector and poverty-related program (including microfinance) during 2001/02 and 2006/07 have succeeded in reducing poverty in Pakistan. At the national level, headcount decreased from 34.46 per cent in 2000-01 to 23.9 per cent in 2004-05, depicting a substantial reduction of 10.5 percentage points over this period. In absolute numbers the count of poor persons has fallen from 49.23 million in 2001 to 36.45 million in 2004-05. While rural poverty declined even more sharply by 11.13 percentage points, urban poverty also declined by 7.75 percentage points. It is generally argued that though poverty has declined in Pakistan, the gap between rich and poor has widened. The result suggests that though consumption inequality in Pakistan has increased marginally during 2001-05, consumption/ income equality in Pakistan is far less compared with many high, middle and low income countries.

Microfinance sector in Pakistan has recorded substantial growth over the past six years as an outcome of a favorable policy and regulatory framework as well as supportive investments undertaken by the Government of Pakistan towards the development of the sector. "Khushali Bank continues to lead and is the largest MFI in the country in term of its network, clients and portfolio. The bank has a presence in 85 districts of the country through a network of 110 service outlets and processed over a million loans worth Rs. 10 billion across 550,000 households with a portfolio that is pre-dominantly rural". (Economic Survey of Pakistan 2007)

Tables 4.3 below indicate the overall Urban-Rural focus of various Microfinance Banks (MFBs), Microfinance Institutions (MFIs) and Rural Support Programmes (RSPs). We can clearly view that the focus is shifting from rural to urban areas of Pakistan from 2005 to 2006.

Table 4.3: Urban Rural Trends in Pakistan

\begin{tabular}{|c|c|c|c|c|c|c|c|c|}
\hline & \multicolumn{2}{|c|}{ MFBS } & \multicolumn{2}{c|}{ MFIs } & \multicolumn{2}{c|}{ RSPs } & \\
\hline & URBAN & RURAL & URBAN & RURAL & URBAN & RURAL & URBAN & RURAL \\
\hline 2005 & $31 \%$ & $69 \%$ & $71 \%$ & $29 \%$ & $11 \%$ & $89 \%$ & $31 \%$ & $69 \%$ \\
\hline 2006 & $40 \%$ & $60 \%$ & $74 \%$ & $26 \%$ & $15 \%$ & $85 \%$ & $39 \%$ & $61 \%$ \\
\hline
\end{tabular}

Source: Pakistan Microfinance Review 2006, p. 15

\subsection{Analysis}

\subsubsection{Analysis of Secondary Data}

A comparative study of table 3.1 and 3.3 from year 2005 to 2006 also reveal that as MFIs are shifting their focus on urban areas from rural areas where their trend is 
decreasing. During the same period, there is an overall decrease in poverty but the percentage of decrease in urban areas is more as compare to rural areas which is very small. It further supplements the success of microfinance programs in alleviating poverty. Microfinance in Pakistan is a relatively new and emerging discipline but it is gaining importance fast as a tool of poverty alleviation. Although impact of microfinance sector in Pakistan is yet to be evaluated, globally it has shown a positive impact on poverty reduction that is significant enough to be recognized.

Some of the findings of the studies related to impact analysis of the microfinance programs on poverty alleviation provided by first quarterly report of State Bank of Pakistan (2005) are:

1. An impact study of KASHF foundation, Pakistan revealed that 94 per cent of its borrowers have experienced positive economic and social changes in their households and 75 per cent of them felt that without this loan it would have not been possible for them to undertake business activities and to generate employment and income.

2. An impact study conducted on Bunyad Literacy Community Council (BLCC), Pakistan by the State Bank of Pakistan, found that its clients have increased their income by 63 per cent. Beneficiaries of micro credit were not only able to increase their earnings, but more importantly, were able to spend more on the education of their children.

\subsubsection{Analysis of Primary Data}

1. A survey of microfinance providers revealed that they could only reach $11 \%$ prospective clients and leaving a large number of clients without the products of microfinance. Therefore we can say that microfinance providers are fail to reach the large number of poor rather core poor clients.

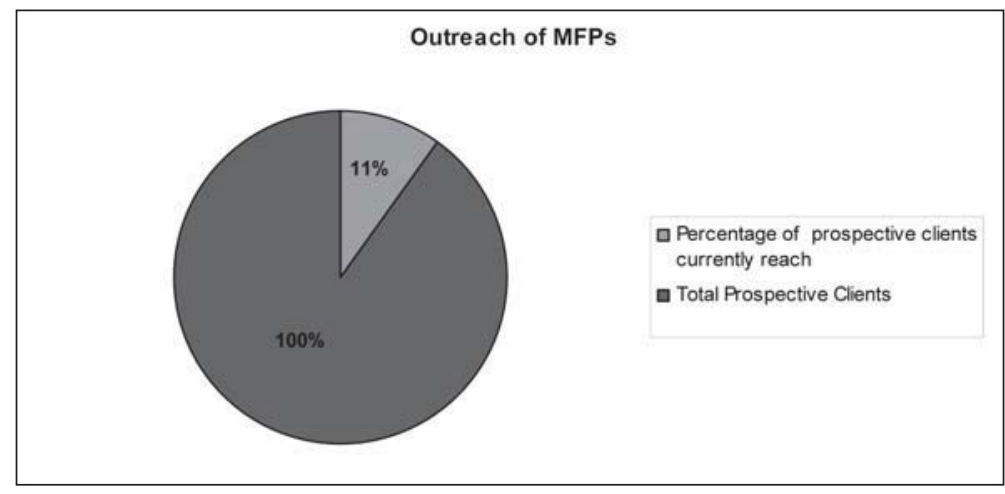

Source: Computed

2. In the same survey above $90 \%$ microfinance providers have observed positive 
impact in various traits of livelihood; like family income, saving, consumption and growth in business. Therefore we can say that microfinance is an effective tool in improving the livelihood of its clients and reducing poverty on macro level. Through microfinance over a period of time people may experience improvement in their income and get chance to avail better health facilities, education for their children and even lead to employment generation.

3. The cost effectiveness of microfinance in reaching the core poor is also an essential part to study and analyze while we study microfinance as a poverty targeting tool. In the survey only $33 \%$ microfinance providers revealed that they are self sustained and not taking any financial assistance. Remaining $67 \%$ are taking financial assistance from either government or international funding agencies to run their programmes. It leads to a conclusion that very few of microfinance providers are self sustained and yet it has not proved itself as a cost effective tool in the current scenario in Pakistan.

\section{Conclusion}

Some valuable conclusions can be drawn from the experiences of successful Microfinance operation. First of all, the poor repay their loans and are willing to pay providing access to credit is given. The community group pressure and sequential lending provide strong repayment motivation and produce extremely low default rates. Secondly, the poor save and hence microfinance should provide both savings and loan facilities. These two findings imply that banking with the poor can not only be a profitable business but also can have macro impact if individuals successfully improve their financial and living standards.

While reaching at these conclusions proved through various success stories, we should also analyze other factors responsible for not achieving the desired results of microfinance in Pakistan. For example, surge in food and fuel prices, poor agricultural performance and slower economic growth erode the success of microfinance in reducing poverty. A promising solution is to provide multi-purpose loans or composite credit, which not only meant for income generation but also provide consumption support. Consumption loan is found to be especially important during the gestation period between commencing a new economic activity and deriving positive income. Careful research on demand for financing and savings behavior of the potential borrowers and their participation in determining the mix of multi-purpose loans are essential in making the concept work. 


\section{References}

Dr. Younus (2006), Paving the Way out of Poverty, Time Magazine, October 13, 2006.

Government of Pakistan (2005), Economic Survey of Pakistan, Ministry of Finance, Islamabad, p. 2.

Government of Pakistan (2007), Economic Survey of Pakistan, Ministry of Finance, Islamabad, pp. 62-63.

Government of Pakistan (2007), Economic Survey of Pakistan, Ministry of Finance, Islamabad, pp. 18-31

Government of Pakistan (2008), Economic Survey of Pakistan, Ministry of Finance, Islamabad, pp. 216-217

Heen, Stacy Michelle (2004), Microfinance and Conflict: Toward a Conflict-Sensitive Approach, The Fletcher School, p. 2

Muhammad Yunus (2004), Grameen Bank at a Glance, January 2004, www.grameeninfo.org/bank/GBGlance.htm

Nafziger (1997), The Economics of Developing Countries, Prentice Hall, pp. 127-128.

Pakistan Microfinance Review (2006), and Performance Indicators Report (2005), Pakistan Microfinance Network, Islamabad.

Richard Adams (2003), Economic Growth, Inequality and Poverty: Findings from a New Dataset, World Bank's Poverty Reduction Network.

http://info.worldbank.org/etools/BSPAN/PresentationView.asp?EID=399\&PID=783

State Bank of Pakistan (2005), The State of Pakistan's Economy; First Quarterly Report for FY05, pp.105-112.

UNDP (2009), Human Development Index, Human Development Report 2009, UNDP available at;

http://hdrstats.undp.org/en/countries/country_fact_sheets/cty_fs_PAK.html 